\title{
Indirect somatic embryogenesis and regeneration of Fraxinus mandshurica plants via callus tissue
}

\author{
Yang Liu ${ }^{1,2}$ Cheng Wei ${ }^{1,2} \cdot$ Hao Wang ${ }^{1,2} \cdot$ Xiao Ma ${ }^{1,2}$. \\ Hailong Shen $^{1,2} \cdot$ Ling Yang ${ }^{1,2}$
}

Received: 10 May 2020 / Accepted: 27 June 2020 / Published online: 7 August 2020

(C) The Author(s) 2020

\begin{abstract}
Somatic embryogenesis of Fraxinus mandshurica has the problems of low somatic embryo (SE) yield, unsynchronized SE development, and a high percentage of deformed SEs. We aimed to improve $F$. mandshurica SE production by synchronizing SE development, improving SE quality, and inducing root formation to obtain complete regenerated plants. Cotyledons of immature zygotic embryos of $F$. mandshurica were induced to form callus and then SEs. The SE induction percentage from explants differed among 32 mother trees, and the one with the highest SE induction percentage (29.8\%) was used for further experiments. The highest callus induction percentage was 94.2\% on $1 / 2$-strength Murashige and Skoog medium (MS1/2)
\end{abstract}

Yang Liu and Cheng Wei contributed equally to this work.

Project funding: The work was supported by the Fundamental Research Funds for the Central Universities of China (2572018BW02), the National Natural Science Foundation of China (31400535 and 31570596), the Innovation Project of State Key Laboratory of Tree Genetics and Breeding (2016C01) and the National Key R\&D Program of China (2017YFD0600600).

The online version is available at http://www.springerlink.com

Corresponding editor: Yu Lei

Hailong Shen

shenhl-cf@nefu.edu.cn

Ling Yang

yangl-cf@nefu.edu.cn

1 State Key Laboratory of Tree Genetics and Breeding, Northeast Forestry University, Harbin 150040,

People's Republic of China

2 State Forestry and Grassland Administration Engineering Technology Research Center of Native Tree Species, Harbin 150040, People's Republic of China supplemented with $0.15 \mathrm{mg} \cdot \mathrm{L}^{-1}$ naphthalene acetic acid. The highest callus proliferation coefficient (240.5) was obtained on McCown's Woody Plant Medium containing $0.1 \mathrm{mg} \cdot \mathrm{L}^{-1}$ 6-benzyl adenine and $0.15 \mathrm{mg} \cdot \mathrm{L}^{-1}$ 2, 4-dichlorophenoxyacetic acid. The highest number of SEs $\left(1020.5 \mathrm{~g}^{-1}\right.$ fresh weight) was obtained on MS1/2 medium supplemented with $1 \mathrm{mg} \cdot \mathrm{L}^{-1}$ 6-benzyladenine. The highest number of cotyledon embryos (397/g fresh weight) was obtained by incubating materials on medium containing $1 \mathrm{mg} \cdot \mathrm{L}^{-1}$ abscisic acid and then applying a drying treatment. The cotyledon embryos were milky white, uniformly sized (average length $4.7 \mathrm{~mm}$ ), and $80 \%$ of them were normal. The SE rooting percentage on $1 / 2 \mathrm{MS}$ medium containing $0.01 \mathrm{mg} \cdot \mathrm{L}^{-1} \mathrm{NAA}$ was $37.5 \%$. Overall, the germination percentage of SEs was $26.4 \%$, and complete regenerated plants were obtained after transplanting and acclimation. These results provide more possibilities for the preservation and breeding of F. mandshurica.

Keywords Fraxinus mandshurica $\cdot$ Somatic embryogenesis - Callus induction - Cell differentiation · Plant regeneration

\begin{tabular}{|c|c|}
\hline \multicolumn{2}{|c|}{ Abbreviations } \\
\hline $1 / 3 \mathrm{MS}$ & $\begin{array}{l}\text { Medium with one-third strength of the macroele- } \\
\text { ments of murashige and skoog (1962) }\end{array}$ \\
\hline 2,4-D & 2,4-Dichlorophenoxyacetic acid \\
\hline ABA & Abscisic acid \\
\hline BA & 6-Benzyladenine \\
\hline $\mathrm{CH}$ & Casein hydrolysate \\
\hline IAA & Indoleacetic acid \\
\hline IBA & Indole-3-butyric acid \\
\hline MS & Medium of murashige and skoog (1962) \\
\hline $\mathrm{MS}^{1} / 2$ & $\begin{array}{l}\text { Medium with one-half-strength of all elements of } \\
\text { MS }\end{array}$ \\
\hline NAA & Naphthaleneacetic acid \\
\hline
\end{tabular}


SE(s) Somatic embryo(s)

WPM Woody plant medium

\section{Introduction}

Somatic embryogenesis is not only a valuable model for embryo cell biology and molecular biology research (LeluWalter et al. 2013; Us-Camas et al. 2014), but also an effective system for plant germplasm innovation and large-scale propagation of excellent germplasm resources (Park 2014). The complex process of somatic embryogenesis depends on genotype and is influenced and regulated by many other factors. The difficulty in inducing SE varies among different species (Khan et al. 2010). Somatic embryogenesis can be direct or indirect (Guan et al. 2016). Under special conditions, explants directly induce somatic embryos (SEs) as direct somatic embryogenesis, and explants form SEs as indirect somatic embryogenesis by forming callus. Most species undergo somatic embryogenesis indirectly (Corredoira et al. 2013, 2015). As long as there are appropriate explants, culture conditions, and culture environment, most plant species can be induced to form callus and SEs. An indirect somatic embryogenesis system has been established for Castanea mollissima, Carica papaya, and Medicago truncatula, among others (Lu et al. 2017; Solórzano-Cascante et al. 2018; Orłowska and Kępczyńska 2020). For other plants, such as Liriodendron hybrida and Catalpa fargesii, direct and indirect somatic embryogenesis systems produce SEs that can grow into complete plants (Chen et al. 2012; Jiang et al. 2014).

Manchurian ash (Fraxinus mandshurica Rupr.) is a precious broad-leaved tree species in northeastern China. It is cold tolerant, drought resistant, grows rapidly, has a welldeveloped root system, and produces excellent wood with a beautiful texture. F. mandshurica is mainly propagated via seeds, but the seeds have deep dormancy characteristics (Yang et al. 2017). Therefore, the application of asexual reproduction and biotechnology for $F$. mandshurica has great potential. Asexual reproduction of individuals who have been selected, improved, and genetically manipulated can accelerate the breeding process (Lelu-Walter et al. 2013). Over the last 17 years, studies on the somatic embryogenesis of $F$. mandshurica have identified good explant sources for somatic embryogenesis and the optimum period for explant harvesting (Sun et al. 2010), described the physiological and biochemical changes in somatic embryogenesis (Cong et al. 2012), SE maturation, and germination (Yang et al. 2013), documented the proteomic profile of SEs (Liu et al. 2015). In our research, we have found that SEs of $F$. mandshurica can form directly or indirectly via callus. That is, direct somatic embryogenesis and indirect somatic embryogenesis occur on the same explant (Horstman et al. 2017). However, due to the low percentage of callus emergence (6.5\%) (Zhang et al. 2015), callus culture of $F$. mandshurica has received little attention in the past.

The main problems with direct somatic embryogenesis of F. mandshurica are the low SE yield (Yang et al. 2013), unsynchronized SE development (Zhang and Shen 2007; Yang et al. 2013), and genetic instability, all of which restrict large-scale production. In this study, we devised a strategy to increase callus proliferation, improve embryo differentiation, and synchronize embryo development, which ultimately increased the number of $F$. mandshurica SEs and complete regenerated plants. These results lay the foundation for the preservation of excellent germplasm resources of $F$. mandshurica, and for its molecular breeding and large-scale industrial breeding.

\section{Materials and methods}

\section{Plant materials}

Immature (undehydrated, green) seeds of $F$. mandshurica were collected in early August 2017 from fifteen 60-yearold free-pollinated parent trees growing at the University Forest of Northeast Forestry University, Harbin, Heilongjiang Province, China ( $126^{\circ} 37^{\prime} 55^{\prime \prime}$ E, $\left.45^{\circ} 43^{\prime} 16^{\prime \prime} \mathrm{N}\right)$, and from seventeen 40-year-old free-pollinated parent trees growing at Hongguang Forest Farm, Jilin Province, China (127 $45^{\prime} 81^{\prime \prime}$ E, $42^{\circ} 30^{\prime} 41^{\prime \prime} \mathrm{N}$ ).

\section{Explant preparation}

According to the method of Liu et al. (2015), the seeds were soaked for $12 \mathrm{~h}$, disinfected in $75 \%$ alcohol for $10 \mathrm{~s}$, and treated with $2 \%(\mathrm{v} / \mathrm{v})$ sodium hypochlorite solution with continuous agitation for $10 \mathrm{~min}$. The immature embryos were squeezed out with tweezers, then each single cotyledon was cut and placed onto induction medium (10 cotyledons per dish, 5 dishes per treatment). The induction medium (Yang et al. 2013) was $1 / 2$-strength Murashige and Skoog medium ( $\left.\mathrm{MS}^{1 / 2}\right)$ supplemented with $5 \mathrm{mg} \mathrm{L}^{-1}$ naphthalene acetic acid (NAA), $2 \mathrm{mg} \mathrm{L}^{-1}$ benzyl adenine (BA), $400 \mathrm{mg}$ $\mathrm{L}^{-1}$ casein hydrolysate $(\mathrm{CH}), 75 \mathrm{~g} \cdot \mathrm{L}^{-1}$ sucrose, and $3 \mathrm{~g} \mathrm{~L}-1$ gellan gum (Gelrite, G1910, Sigma-Aldrich Co., St Louis, MO, USA). The $\mathrm{pH}$ of the medium was adjusted to 5.8 before high-temperature and high-pressure steam sterilization. The cotyledons were cultured at $25 \pm 2{ }^{\circ} \mathrm{C}$ in the dark, and subcultured every 30 days. The culture status and number of SEs were recorded at $60 \mathrm{~d}$ of culture. 


\section{Callus induction experiment}

After 60-day cultivation, yellowish-brown cell mass (Fig. 1a) and SEs at different developmental stages were carefully removed from the explant surface, then the cell masses and SEs were cut into small pieces and inoculated onto callus induction media ( $0.3 \mathrm{~g}$ of material per dish and 20 replicates per treatment). Two types of callus induction media were tested:

Induction medium I: $\mathrm{MS}^{1} / 2$ containing NAA at different concentrations $\left(0,0.05,0.1,0.15,0.20 \mathrm{mg} \mathrm{L}^{-1}\right), 400 \mathrm{mg} \mathrm{L}^{-1}$ $\mathrm{CH}, 25 \mathrm{~g} \mathrm{~L}^{-1}$ sucrose, and $3 \mathrm{~g} \mathrm{~L}^{-1}$ gellan gum, $\mathrm{pH}=5.8$.

Induction medium II: $\mathrm{MS}^{1} / 2$ containing $0.05 \mathrm{mg} \mathrm{L}^{-1} \mathrm{NAA}$, different concentrations of BA $\left(0,1,2 \mathrm{mg} \mathrm{L}^{-1}\right), 400 \mathrm{mg} \mathrm{L}^{-1}$ $\mathrm{CH}, 25 \mathrm{~g} \mathrm{~L}^{-1}$ sucrose, and $3 \mathrm{~g} \mathrm{~L}^{-1}$ gellan gum, $\mathrm{pH}=5.8$.

The callus induction rate was counted after culturing in the dark at $25 \pm 2{ }^{\circ} \mathrm{C}$ for 1 month.

\section{Callus proliferation experiment}

\section{Experiment 1: cell line selection}

Explants derived from the No. 2 tree at the University Forest of Northeast Forestry University, P. R. China were used in this experiment. Yellowish-brown, translucent, loosely structured callus was removed from different cell lines after 1 month of induction culture. Old and browning cells were removed from the surface of the callus in a clean bench, and then the callus was transferred onto proliferation medium McCown's Woody Plant Medium (WPM) supplemented with $0.15 \mathrm{mg} \mathrm{L}^{-1} 2$, 4-dichlorophenoxyacetic acid (2,4-D), $0.1 \mathrm{mg} \mathrm{L}{ }^{-1} \mathrm{BA}, 20 \mathrm{~g} \cdot \mathrm{L}^{-1}$ sucrose, and $3.5 \mathrm{~g} \mathrm{~L}^{-1}$ gellan gum, $\mathrm{pH}=5.8$ ). The callus proliferation coefficient was calculated after culture in the dark at $25 \pm 2{ }^{\circ} \mathrm{C}$ for 1 month.

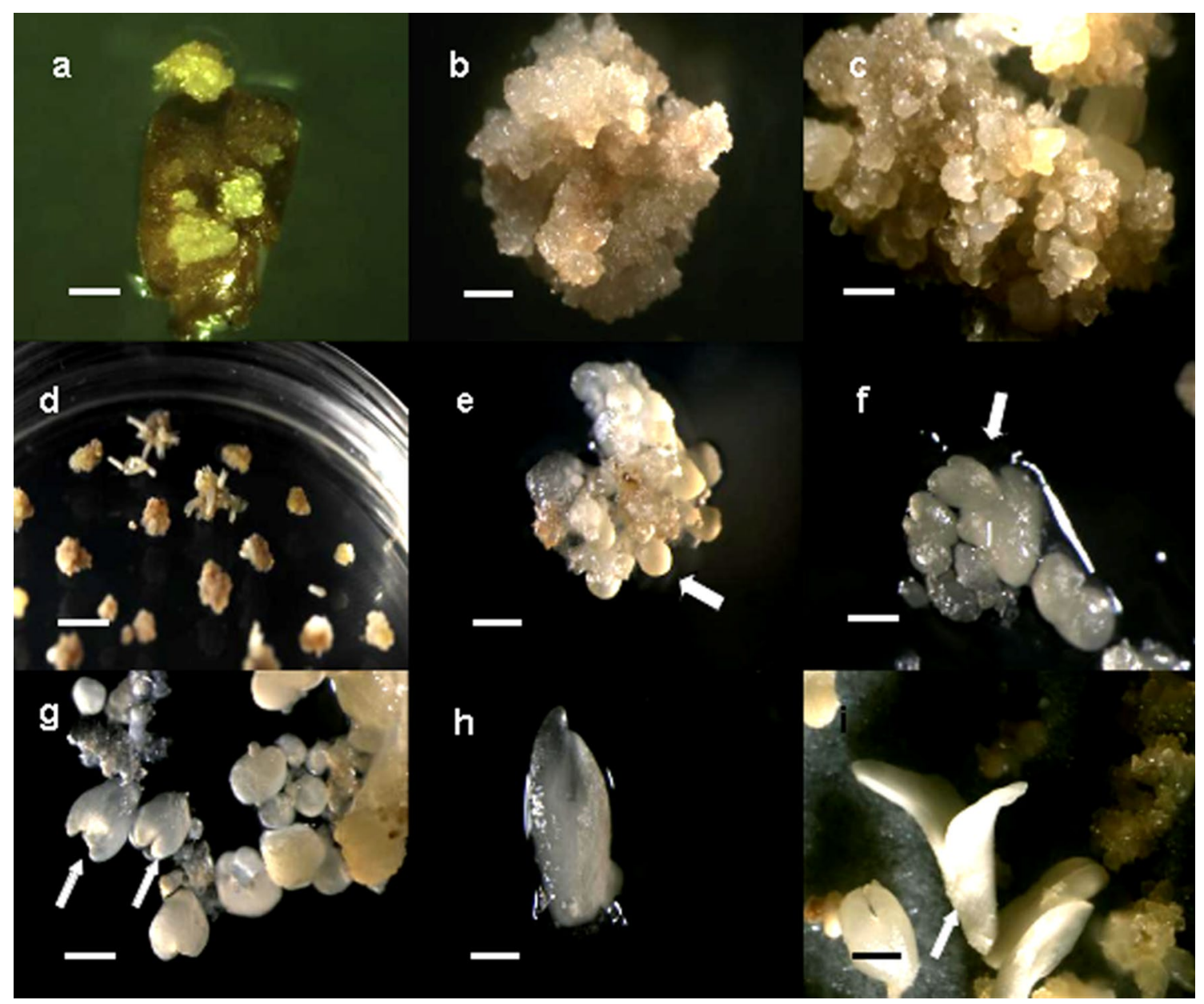

Fig. 1 Indirect somatic embryogenesis of Fraxinus mandshurica. a. Callus induction; b. Embryogenic callus at proliferation stage; $\mathbf{c}$. Early stage of callus differentiation; $\boldsymbol{d}$. Late stage of callus differentiation; e. Globular embryo differentiated from callus; f. Heart-shaped embryo differentiated from callus; g. Torpedo-shaped embryo differentiated from callus; $\mathbf{h}$. Cotyledon embryo differentiated from callus; i. Cotyledon-shaped embryos after maturing for 30 days. Scale bars: $1 \mathrm{~mm}(\mathbf{a}-\mathbf{c}, \mathbf{i}) ; 1 \mathrm{~cm}(\mathbf{d}) ; 1.2 \mathrm{~mm}(\mathbf{e}-\mathbf{h})$ 


\section{Experiment 2: growth regulator selection}

Experiment 1 showed that cell line $2-1$ had a strong proliferation ability, so this cell line was used in Experiment 2. Cells of cell line 2-1 were inoculated onto WPM media supplemented with different concentrations of BA and 2,4-D as described below. The callus proliferation coefficient was calculated after culture in the dark with $25 \pm 2{ }^{\circ} \mathrm{C}$ for 1 month.

Callus proliferation medium I: WPM supplemented with different concentrations of BA $\left(0,0.1\right.$ and $\left.0.2 \mathrm{mg} \mathrm{L}^{-1}\right)$, $0.15 \mathrm{mg} \mathrm{L}^{-1}$ 2,4-D, $20 \mathrm{~g} \mathrm{~L}^{-1}$ sucrose, and $3.5 \mathrm{~g} \mathrm{~L}^{-1}$ gellan gum, $\mathrm{pH}=5.8$.

Callus proliferation medium II: WPM supplemented with different concentrations of 2,4-D $\left(0,0.15\right.$, and $\left.0.3 \mathrm{mg} \mathrm{L}^{-1}\right)$, $0.1 \mathrm{mg} \mathrm{L}^{-1} \mathrm{BA}, 20 \mathrm{~g} \mathrm{~L}^{-1}$ sucrose, and $3.5 \mathrm{~g} \mathrm{~L}^{-1}$ gellan gum, $\mathrm{pH}=5.8$.

\section{Callus differentiation experiment}

Using callus from cell line 2-1 after 1 year of proliferation as the experimental material, we collected embryogenic callus (beige, translucent, granular loose callus) in the clean bench and transferred it onto differentiation media (MS1/2 medium supplemented with different concentrations of NAA and BA). The cells were cultured in the dark at $25 \pm 2{ }^{\circ} \mathrm{C}$ and subcultured every 30 days.

\section{Differentiation medium I}

MS $1 / 2$ medium containing different concentrations of NAA $\left(0,1\right.$, and $\left.2 \mathrm{mg} \cdot \mathrm{L}^{-1}\right), 1 \mathrm{mg} \cdot \mathrm{L}^{-1} \mathrm{BA}, 400 \mathrm{mg} \cdot \mathrm{L}^{-1} \mathrm{CH}$, $20 \mathrm{~g} \cdot \mathrm{L}^{-1}$ sucrose, and $3.5 \mathrm{~g} \cdot \mathrm{L}^{-1}$ gellan gum, $\mathrm{pH}=5.8$.

\section{Differentiation medium II}

$\mathrm{MS} 1 / 2$ medium containing different concentrations of $\mathrm{BA}(0$, 1 , and $\left.2 \mathrm{mg} \cdot \mathrm{L}^{-1}\right), 1 \mathrm{mg} \cdot \mathrm{L}^{-1} \mathrm{NAA}, 400 \mathrm{mg} \cdot \mathrm{L}^{-1} \mathrm{CH}, 20 \mathrm{~g} \cdot \mathrm{L}^{-1}$ sucrose, and $3.5 \mathrm{~g} \cdot \mathrm{L}^{-1}$ gellan gum, $\mathrm{pH}=5.8$.

\section{Somatic embryo maturation experiment}

\section{Drying treatment}

Using the method of (Lelu-Walter et al. 2018), $3 \mathrm{~g}$ of SEs from cell line $2-1$ was added to liquid culture medium $\left(\mathrm{MS}^{1 / 2}+20 \mathrm{~g} \cdot \mathrm{L}^{-1}\right.$ sucrose) in the clean bench. The mixture was shaken, then $0.3 \mathrm{~g}$ of the mixture was poured onto sterilized filter paper in a Buchner funnel. Excess liquid was removed by gentle vacuum, and then the filter paper was spread onto the surface of the maturation culture medium.
Maturation medium

MS1 12 medium containing different concentrations of ABA $\left(0,1,1.5\right.$, and $\left.2 \mathrm{mg} \cdot \mathrm{L}^{-1}\right), 400 \mathrm{mg} \cdot \mathrm{L}^{-1} \mathrm{CH}, 20 \mathrm{~g} \cdot \mathrm{L}^{-1}$ sucrose, $1 \mathrm{~g} \cdot \mathrm{L}^{-1}$ activated carbon, and $3.5 \mathrm{~g} \cdot \mathrm{L}^{-1}$ gellan gum, $\mathrm{pH}=5.8$. The same materials cultured on ABA-free medium without drying were used as the control $(\mathrm{CK})$, and the other conditions were the same as above.

After culture in the dark at $25 \pm 2{ }^{\circ} \mathrm{C}$ for 30 days, the materials were cultured for 2 weeks in light conditions (40 $\mu \mathrm{mol} \mathrm{m}{ }^{-2} \mathrm{~s}^{-1}$; 16-h light/8-h dark photoperiod), and then transferred to MS1/2 medium for a further 30-day culture in the dark (Chen et al. 2019).

\section{Somatic embryo germination and rooting experiment}

The white, elongated cotyledon-shaped embryos obtained from the maturation culture were used as materials for root culture. The basic medium was 1/3-strength MS, and four different germination media were produced by adding different concentrations of NAA, indole butyric acid (IBA), and IAA, as follows:

Germination medium I: $1 / 3 \mathrm{MS}+0.01 \mathrm{mg} \cdot \mathrm{L}^{-1} \mathrm{NAA}$ (Yang et al. 2013);

Germination medium II: $1 / 3 \mathrm{MS}+0.01 \mathrm{mg} \cdot \mathrm{L}^{-1}$ $\mathrm{NAA}+2 \mathrm{~g} \cdot \mathrm{L}^{-1}$ activated carbon;

Germination medium III: $1 / 3 \mathrm{MS}+1.0 \mathrm{mg} \cdot \mathrm{L}^{-1}$ IBA + $1.0 \mathrm{mg} \cdot \mathrm{L}^{-1} \mathrm{IAA}$ (Du and Pijut 2008);

Germination medium IV: $1 / 3 \mathrm{MS}+0.5 \mathrm{mg} \cdot \mathrm{L}^{-1}$ $\mathrm{IBA}+0.5 \mathrm{mg} \cdot \mathrm{L}^{-1} \mathrm{IAA}$.

All germination media contained $20 \mathrm{~g} \cdot \mathrm{L}^{-1}$ sucrose and $3.5 \mathrm{~g} \cdot \mathrm{L}^{-1}$ gellan gum, $\mathrm{pH}=5.8$.

The embryos were cultured at $25 \pm 2{ }^{\circ} \mathrm{C}$ under a $16-\mathrm{h}$ light/8-h dark photoperiod with a light intensity of $40 \mu \mathrm{mol} \mathrm{m} \mathrm{m}^{-2} \mathrm{~s}^{-1}$. The germination and rooting of SE seedlings were observed and recorded.

\section{Plant regeneration and acclimatization}

Rooted, well-developed SEs were transplanted into a plastic container filled with substrate (peat soil: vermiculite: perlite (v:v:v)=5:3:2). The substrate was mixed with MS liquid medium, autoclaved, and then allowed to cool. The culture medium was washed from the roots of the SEs before transplanting. Immediately after transplanting, the SEs were covered with plastic wrap and cultivated in a culture room at $25 \pm 2{ }^{\circ} \mathrm{C}$ under natural light, with daily irrigation to maintain high air humidity. After 15-day culture, the plastic wrap was gradually removed and materials were transferred to $25 \pm 2{ }^{\circ} \mathrm{C}$ under light at $40 \mu \mathrm{mol} \mathrm{m} \mathrm{m}^{-2} \mathrm{~s}^{-1}$. The plantlets were watered daily during transplanting and acclimatization. 


\section{Statistical analysis}

Data were collated with Microsoft Excel 2007 (USA). We used SPSS software (2015, v.23, SPSS Inc., Chicago, IL, USA) for one-way analysis of variance of the SE induction rate, callus state coefficient, callus induction percentage, fresh weight multiplication factor, proliferation coefficient, SE induction percentage, number of SEs, SE rooting percentage, and SE sprouting percentage. Sigmaplot (2011, v.12.5, SYSTAT, USA) software was used to draw graphs. We used the following calculations to obtain various rates and indexes:
$(P<0.05)$. SEs formed explants from 7 out of 17 mother trees growing at Hongguang Forest Farm, and the highest SE induction percentage (16\%) was from mother tree No.21. The SE induction percentage was higher for trees growing at University Forest than for trees growing at Hongguang Forest Farm, but the difference was not significant $(P>0.05)$. Thus, the SE induction percentage from immature zygotic embryos of $F$. mandshurica was not related to region, but was related to the genotype of the mother tree. We selected materials from mother tree No. 2 for subsequent experiments (Table 1).

SEinduction percentage $(\%)=\frac{\text { Number of explants with somatic embryogenesis }}{\text { Number of surviving explants inoculated }} \times 100$

Callus state coefficient $(\%)=\frac{\text { Number of callus in good condition }}{\text { Number of callus inoculated }} \times 100$

Callus induction percentage $(\%)=\frac{\text { Number of explants producing callus }}{\text { Number of surviving explants inoculated }} \times 100$

Fresh weight multiplication factor $(\%)=\frac{\text { Weight of callus after proliferation }}{\text { Weight of callus during inoculation }} \times 100$

$$
\text { Number of SEs }(\mathrm{a} / \mathrm{g})=\frac{\text { Number of embryos induced }}{\text { Weight of callus }}
$$

Rooting percentage $(\%)=\frac{\text { Number of SEs rooting }}{\text { Number of SEs inoculated }} \times 100$

\section{Callus induction}

When the concentration of NAA remained constant and the BA concentration increased, the callus induction percentage decreased (Fig. 2a). The highest callus induction percentage $(9.9 \%)$ was on medium containing only $0.05 \mathrm{mg} \mathrm{L}^{-1}$

Germination percentage $(\%)=\frac{\text { Number of SEs with new shoots }}{\text { Number of SEs inoculated }} \times 100$

\section{Results}

\section{Explant preculture results}

After 60-day pre-cultivation, we calculated the frequency of SEs formed from explants from 32 different $F$. mandshurica mother trees from two forest farms (Table 1). The frequency of SEs differed significantly among the mother trees $(P<0.05)$. SEs formed from explants from 7 out of 15 mother trees growing at the University Forest, Northeast Forestry University, China. The highest SE induction rate $(29.8 \%)$ was from mother tree No.2, and this rate was significantly higher than those for the other mother trees
NAA, and the lowest (1.5\%) was on medium containing $0.05 \mathrm{mg} \mathrm{L}^{-1} \mathrm{NAA}$ and $2 \mathrm{mg} \mathrm{L}^{-1} \mathrm{BA}$. Thus, BA inhibited callus induction.

On medium containing only NAA, in the concentration range of 0 to $0.15 \mathrm{mg} \mathrm{L}^{-1}$, the callus induction percentage increased with the increase of NAA concentration $(P<0.05)$ (Fig. 2b). The highest callus induction percentage (94.2\%) was on medium containing $0.15 \mathrm{mg} \mathrm{L}^{-1} \mathrm{NAA}$ and the lowest (76.7\%) was on medium $0.2 \mathrm{mg} \mathrm{L}^{-1} \mathrm{NAA}(P<0.05)$. Thus, an appropriate concentration of NAA was beneficial for $F$. mandshurica callus induction. 
Table 1 Somatic embryo induction from different mother trees of Fraxinus mandshurica

\begin{tabular}{llll}
\hline $\begin{array}{l}\text { Mother trees of } \\
\text { Northeast For- } \\
\text { estry University }\end{array}$ & $\begin{array}{l}\text { Somatic embryo } \\
\text { induction (\%) }\end{array}$ & $\begin{array}{l}\text { Mother trees } \\
\text { of } \\
\text { Hongguang } \\
\text { forest farm }\end{array}$ & $\begin{array}{l}\text { Somatic embryo } \\
\text { induction (\%) }\end{array}$ \\
\hline 2 & $29.8 \pm 5.8 \mathrm{a}$ & L1 & $0 \mathrm{a}$ \\
4 & $2.0 \pm 2.0 \mathrm{c}$ & L2 & $0 \mathrm{a}$ \\
10 & $0 \mathrm{c}$ & L3 & $0 \mathrm{a}$ \\
11 & $0 \mathrm{c}$ & L4 & $0 \mathrm{a}$ \\
12 & $0 \mathrm{c}$ & L5 & $10.0 \pm 5.5 \mathrm{bc}$ \\
13 & $0 \mathrm{c}$ & L6 & $0 \mathrm{a}$ \\
14 & $2.5 \pm 2.5 \mathrm{c}$ & L7 & $0 \mathrm{a}$ \\
15 & $6.0 \pm 4.0 \mathrm{c}$ & L9 & $0 \mathrm{a}$ \\
16 & $0 \mathrm{c}$ & L10 & $2.0 \pm 2.0 \mathrm{ab}$ \\
17 & $0 \mathrm{c}$ & L12 & $0 \mathrm{a}$ \\
18 & $6.0 \pm 2.5 \mathrm{c}$ & L13 & $0 \mathrm{a}$ \\
19 & $0 \mathrm{c}$ & L14 & $8.0 \pm 4.9 \mathrm{ab}$ \\
20 & $15.0 \pm 6.5 \mathrm{~b}$ & L15 & $10.0 \pm 3.2 \mathrm{bc}$ \\
21 & $4.0 \pm 4.0 \mathrm{c}$ & L16 & $2.0 \pm 2.0 \mathrm{ab}$ \\
22 & $0 \mathrm{c}$ & L17 & $0 \mathrm{a}$ \\
& & L18 & $3.3 \pm 3.3 \mathrm{ab}$ \\
& & L21 & $16.0 \pm 6.8 \mathrm{c}$ \\
\hline
\end{tabular}

Note: Data are mean \pm standard deviation. Different lowercase letters in the same column numbers indicate significant differences $(P=0.05)$

\section{Callus proliferation}

\section{Cell line selection}

A comparative analysis of the state coefficients of callus from 40 cell lines is shown in Table 2 . The coefficient of callus state differed significantly among different cell lines. The highest callus state coefficient (100\%) was for cell line 2-1 (the No. 1 genotype of the No. 2 tree from University Forest, Northeast Forestry University, China). Therefore, cell line 2-1 was used for subsequent experiments.

\section{Plant growth regulator selection}

Different plant growth regulators significantly affected callus proliferation of $F$. mandshurica (Table 3). (1) The highest fresh weight proliferation coefficient of callus $(240.5 \%)$ was on medium containing $0.1 \mathrm{mg} \mathrm{L}^{-1} \mathrm{BA}$ and $0.15 \mathrm{mg} \mathrm{L}^{-1} 2,4-$ D. On that medium, the callus was yellowish-brown and loose. In addition, granular embryogenic callus formed, from which SEs differentiated later (Fig. 1b). (2) The fresh weight proliferation coefficient of callus was also high (228.7\%) on medium without BA, but the callus was soft, excessively wet, and non-granular (no SEs differentiated later). (3) On medium without 2,4-D, callus showed poor proliferation,
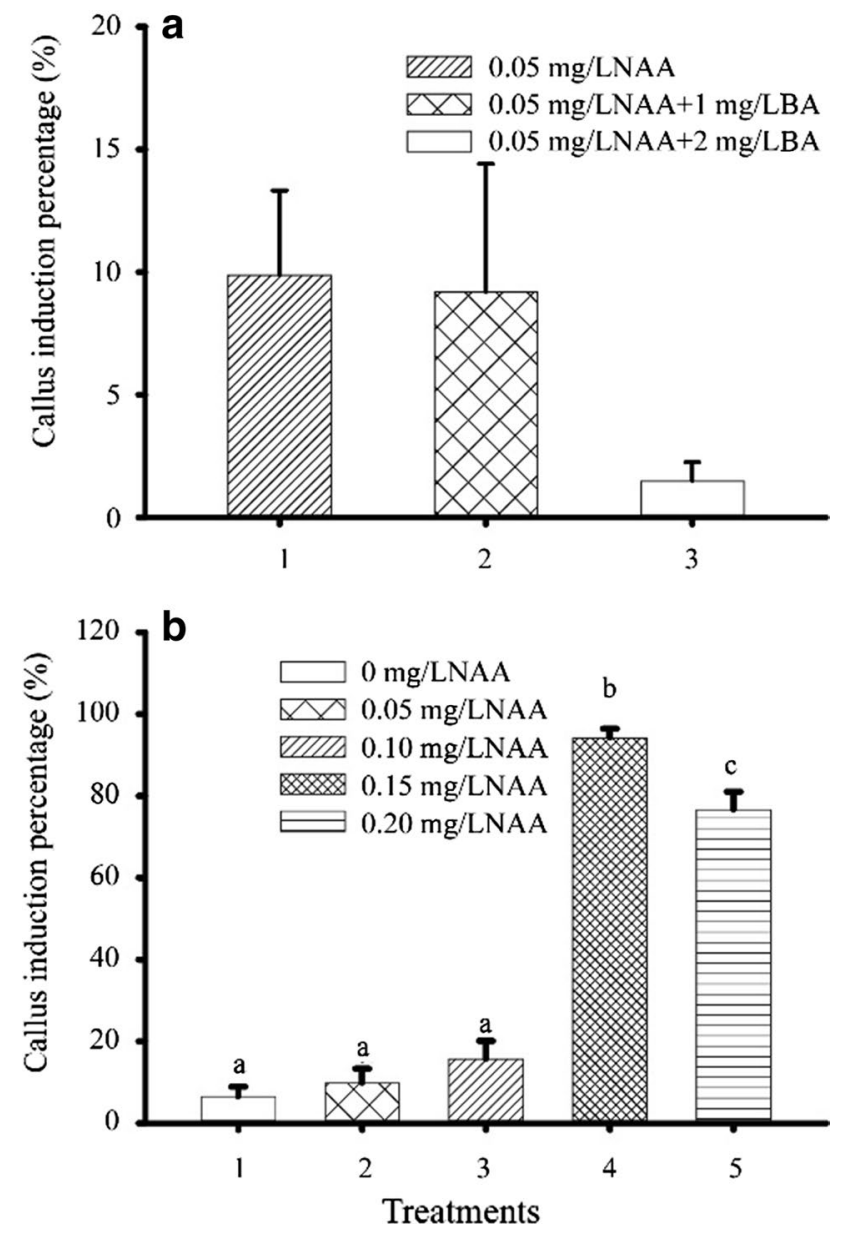

Fig. 2 Effects of NAA and BA on embryogenic callus induction of Fraxinus mandshurica. a Callus induction percentage on medium containing $0.05 \mathrm{mg} \cdot \mathrm{L}^{-1} \mathrm{NAA}$ and increasing concentrations of BA. b Callus induction percentage on medium containing increasing concentrations of NAA only

severe browning, a hard texture, and a block shape. On that medium, the fresh weight proliferation coefficient of callus was $111.3 \%$ after 30 -day culture, and the callus showed little growth.

The callus differentiation process is shown in Fig. 1c-h. Callus differentiation of $F$. mandshurica was positively affected by BA, but not by NAA (Table 4). As the BA concentration in the medium increased, the percentage of callus differentiation into SEs first increased and then decreased. At 30 days of culture, the highest induction percentage of SEs $\left(118.8 \mathrm{~g}^{-1} ; 5.9\right.$ SEs per callus) was on medium containing $1 \mathrm{mg} \cdot \mathrm{L}^{-1} \mathrm{BA}$, and after 90 days of culture, these values had increased to $1025.5 \cdot \mathrm{g}^{-1}$ and 51 SEs per callus. These values were significantly higher than those in the other treatments $(P<0.05)$. The lowest induction percentage of SEs $\left(17.7 \mathrm{~g}^{-1}\right)$ at 30 days of culture was on medium without BA. The lowest number of SEs per callus (0.9) was on medium containing $1 \mathrm{mg} \cdot \mathrm{L}^{-1} \mathrm{NAA}$. 
The frequency of globular embryos was the highest (73\%) in the early stage of differentiation culture (Table 5). As the culture time extended to 90 days, the frequency of heartshaped and cotyledon-shaped embryos increased. When only $1 \mathrm{mg} \mathrm{L}^{-1}$ NAA was added to the medium, the synchronization of SE development was best, and the frequency of cotyledon-shaped embryos was the highest. The frequencies of torpedo-shaped and cotyledon-shaped embryos decreased, and cotyledon-shaped embryos were significantly lower on medium containing $2 \mathrm{mg} \mathrm{L}^{-1} \mathrm{NAA}$ and $1 \mathrm{mg} \mathrm{L}^{-1} \mathrm{BA}$ $(P<0.05)$ than on the other types of media.

\section{Somatic embryo maturation}

A white-opaque appearance was the criterion for maturation of $F$. mandshurica SEs. The effect of ABA on SE maturation is shown in Figs. 3a-e and Table 6. Undried cotyledonshaped embryos cultured on maturation medium without ABA (CK) for 30 days (Fig. 3a) formed abundant cotyledon embryos $\left(320.7 \mathrm{~g}^{-1}\right)$, but the cotyledons were translucent, curled, and stunted, with a high rate of malformation and browning. At 30 days after the drying treatment, the number of cotyledon embryos (Fig. 3c) on medium containing $1 \mathrm{mg} \mathrm{L}^{-1} \mathrm{ABA}$ was $397 \mathrm{~g}^{-1}$, and the cotyledons developed well, with the cotyledons accounting for $51 \%$ of the total embryo length (average length, $4.7 \mathrm{~mm}$ ). The cotyledons were healthy, milky white, stretched, and elongated, with a uniform size and a low rate of malformation. The lowest number of cotyledon embryos $\left(189.6 \mathrm{~g}^{-1}\right)$ was medium containing $2 \mathrm{mg} \mathrm{L}^{-1}$ ABA (Fig. 3e). Their average length was $3.31 \mathrm{~mm}$, and the cotyledon embryos were translucent and stunted with a high rate of malformation.

Transfer the cotyledon embryos to PGR-free medium in the dark culture for 30 days. During this time, the materials that had been cultured on medium containing higher concentrations of ABA showed significantly inhibited SE maturation (Figs. $3 \mathrm{f}-\mathrm{j}$, Table 7). During the 30 days of culture in the dark, the number of cotyledon embryos (Fig. $3 \mathrm{~h}$ ) treated with drying and $1 \mathrm{mg} \cdot \mathrm{L}^{-1} \mathrm{ABA}$ increased to $624 \mathrm{~g}^{-1}(1.57$ times higher than before); the average length was $9.60 \mathrm{~mm}$ (significantly higher than in other treatments, $P<0.05$ ); and the proportion of cotyledon length out of total embryo length decreased by $11 \%$ (significantly lower than in other treatments, $P<0.05$ ). The embryos in this treatment showed the lowest browning percentage $(0.2 \%)$; the highest rooting percentage $(37.99 \%, P<0.05)$; and the lowest percentage of malformation (10\%). However, for the materials that had been cultured on medium containing a higher concentration of ABA (2 mg. $\left.\mathrm{L}^{-1}\right)$ (Fig. 3j), the number of cotyledon embryos was only $176.7 \mathrm{~g}^{-1}$ (about $1 / 4$ of that formed in the $1 \mathrm{mg} \cdot \mathrm{L}^{-1} \mathrm{ABA}$ treatment); and the proportion of cotyledon length to total embryo length was increased (74\%). The embryos in this treatment showed the lowest rooting
Table 2 Callus state coefficients of different cell lines of Fraxinus mandshurica

\begin{tabular}{|c|c|c|c|}
\hline $\begin{array}{l}\text { Cell } \\
\text { line }\end{array}$ & $\begin{array}{l}\text { Callus in } \\
\text { good condition }\end{array}$ & $\begin{array}{l}\text { Total } \\
\text { callus }\end{array}$ & $\begin{array}{l}\text { Callus state } \\
\text { coefficient (\%) }\end{array}$ \\
\hline 1 & 25.0 & 25.0 & 100.0 \\
\hline 2 & 7.0 & 16.0 & 43.8 \\
\hline 3 & 6.0 & 8.0 & 75.0 \\
\hline 4 & 3.0 & 15.0 & 20.0 \\
\hline 5 & 0 & 3.0 & 0 \\
\hline 6 & 18.0 & 20.0 & 90.0 \\
\hline 7 & 6.0 & 11.0 & 54.5 \\
\hline 8 & 0 & 7.0 & 0 \\
\hline 9 & 3.0 & 10.0 & 30.0 \\
\hline 10 & 1.0 & 17.0 & 5.9 \\
\hline 11 & 10.0 & 16.0 & 62.5 \\
\hline 12 & 1.0 & 9.0 & 11.1 \\
\hline 13 & 0 & 7.0 & 0 \\
\hline 14 & 0 & 5.0 & 0 \\
\hline 15 & 0 & 6.0 & 0 \\
\hline 16 & 5.0 & 20.0 & 25.0 \\
\hline 17 & 0 & 10.0 & 0 \\
\hline 18 & 0 & 7.0 & 0 \\
\hline 19 & 13.0 & 18.0 & 72.2 \\
\hline 20 & 11.0 & 15.0 & 73.3 \\
\hline 21 & 0 & 10.0 & 0 \\
\hline 22 & 1.0 & 11.0 & 9.1 \\
\hline 23 & 0 & 8.0 & 0 \\
\hline 24 & 0 & 8.0 & 0 \\
\hline 25 & 0 & 8.0 & 0 \\
\hline 26 & 0 & 7.0 & 0 \\
\hline 27 & 0 & 9.0 & 0 \\
\hline 28 & 0 & 4.0 & 0 \\
\hline 29 & 1.0 & 8.0 & 12.5 \\
\hline 30 & 0 & 9.0 & 0 \\
\hline 31 & 5 & 15.0 & 33.3 \\
\hline 32 & 8.0 & 14.0 & 57.1 \\
\hline 33 & 9.0 & 16.0 & 56.3 \\
\hline 34 & 13.0 & 16.0 & 81.3 \\
\hline 35 & 10.0 & 16.0 & 62.5 \\
\hline 36 & 6.0 & 11.0 & 54.5 \\
\hline 37 & 0 & 8.0 & 0 \\
\hline 38 & 11.0 & 15.0 & 73.3 \\
\hline 39 & 6.0 & 13.0 & 46.2 \\
\hline 40 & 8.0 & 14.0 & 57.1 \\
\hline
\end{tabular}

percentage (8.2\%) and the highest percentage of malformation (85\%). Undried cotyledon embryos cultured without $\mathrm{ABA}(\mathrm{CK})$ (Fig. 3f) formed a large number of cotyledon embryos $\left(961.7 \mathrm{~g}^{-1}\right)$, but the browning percentage (24.9\%) was significantly higher than that in other treatments, and the 
embryos were curled and stunted, which was not conducive to later SE development.

\section{Somatic embryo germination and rooting}

Next, the SEs were transferred to fresh media for germination and rooting (Fig. $4 \mathrm{a}-\mathrm{b}$ ). The culture conditions significantly affected the germination of SEs $(P<0.05$, Table 8$)$. Low concentrations of auxin were beneficial for the rooting of SEs (Table 8 ). The highest rooting and germination percentage of SEs (37.5\% and $26.4 \%$, respectively) were on GM I medium (1/3 MS + $\left.0.01 \mathrm{mg} \cdot \mathrm{L}^{-1} \mathrm{NAA}\right)$. However, the rooting and germination percentage of SEs were inhibited on GM II medium (GM I with the addition of activated carbon). The lowest rooting and germination percentages of SEs $(0 \%$ and $5.6 \%$, respectively) were on GM III medium, which had a high concentration of auxins $\left(1.0 \mathrm{mg} \mathrm{L}^{-1} \mathrm{IBA}+1.0 \mathrm{mg}\right.$ $\mathrm{L}^{-1}$ IAA). On GM III medium, the SEs did not take root and barely grew, but the hypocotyl elongated. On GM IV medium, which had half the concentrations of IBA and IAA in GM III, the rooting and germination rates of SEs were significantly increased.

\section{Plant regeneration and acclimatization}

Before transplanting, the SE seedlings were acclimated for 3 days in a domestication room. At 15 days after transplanting, the survival percentage was $100 \%$. Seedlings showed strong growth with extended leaves, new pinnate compound leaves, and an average seedling height of $3.75 \mathrm{~cm}$. At 30 days after transplanting, the average seedling height was $6.29 \mathrm{~cm}$. At 60 days after transplanting, the survival percentage was $90.9 \%$ and the average seedling height was $9.26 \mathrm{~cm}$ (Fig. 4c).

\section{Discussion}

\section{Induction of embryogenic callus}

In this study, an appropriate concentration of auxin positively affected callus induction from $F$. mandshurica. In the range of 0.1 to $0.15 \mathrm{mg} \mathrm{L}^{-1} \mathrm{NAA}$, the callus induction percentage increased significantly with increasing NAA concentrations (Fig. 2b). In Fraxinus excelsior, the embryogenic callus induction needed the combination of 2,4-D and 6-BA (Ozudogru et al. 2010). Previous studies have demonstrated that the induction of plant callus by plant growth regulators
Table 3 Fresh weight multiplication coefficient of Fraxinus mandshurica callus (\%)

Table 4 Callus differentiation in Fraxinus mandshurica

\begin{tabular}{|c|c|c|c|c|c|c|}
\hline \multicolumn{2}{|c|}{$\begin{array}{l}\text { PGR (mg } \\
\left.\mathrm{L}^{-1}\right)\end{array}$} & \multicolumn{4}{|l|}{ Culture time (d) } & \multirow[t]{2}{*}{ Callus status } \\
\hline BA & $2,4-\mathrm{D}$ & 3 & 9 & 15 & 30 & \\
\hline 0 & 0.15 & $173.1 \pm 44.3 \mathrm{ab}$ & $491.8 \pm 131.6 \mathrm{a}$ & $191.8 \pm 21.5 \mathrm{a}$ & $228.7 \pm 20.1 \mathrm{a}$ & Soft, non-granular \\
\hline 0.1 & 0.15 & $261.6 \pm 49.9 \mathrm{a}$ & $287.0 \pm 45.4 \mathrm{ab}$ & $181.1 \pm 20.2 \mathrm{a}$ & $240.5 \pm 32.5 \mathrm{a}$ & loose, granular \\
\hline 0.2 & 0.15 & $161.4 \pm 29.5 \mathrm{ab}$ & $227.8 \pm 56.7 b$ & $126.4 \pm 4.0 \mathrm{~b}$ & $178.2 \pm 12.7 \mathrm{ab}$ & Slightly hard, granular \\
\hline 0.1 & 0 & $106.2 \pm 25.5 b$ & $147.1 \pm 29.6 b$ & $101.9 \pm 7.2 b$ & $111.3 \pm 14.5 b$ & Severe browning, lumpy \\
\hline 0.1 & 0.15 & $261.6 \pm 49.9 a$ & $287.0 \pm 45.4 \mathrm{ab}$ & $181.1 \pm 20.2 \mathrm{a}$ & $240.5 \pm 32.5 a$ & loose, granular \\
\hline 0.1 & 0.3 & $128.2 \pm 8.3 b$ & $148.4 \pm 8.2 b$ & $137.3 \pm 21.7 \mathrm{ab}$ & $175.3 \pm 40.4 \mathrm{ab}$ & hard, granular \\
\hline
\end{tabular}

Note: Data are mean \pm standard deviation. Different lowercase letters in the same column numbers indicate significant differences $(P=0.05)$

\begin{tabular}{|c|c|c|c|c|c|}
\hline \multicolumn{2}{|c|}{$\begin{array}{l}\text { PGR (mg } \\
\left.\mathrm{L}^{-1}\right)\end{array}$} & \multicolumn{2}{|l|}{ Cultured $30 \mathrm{~d}$} & \multicolumn{2}{|l|}{ Cultured $90 \mathrm{~d}$} \\
\hline NAA & $\mathrm{BA}$ & $\begin{array}{l}\text { Number of somatic } \\
\text { embryos } \cdot\left(\mathrm{g}^{-1}\right)\end{array}$ & $\begin{array}{l}\text { Number of somatic } \\
\text { embryos per callus }\end{array}$ & $\begin{array}{l}\text { Number of somatic } \\
\text { embryos }\left(\mathrm{g}^{-1}\right)\end{array}$ & $\begin{array}{l}\text { Number of somatic } \\
\text { embryos per callus }\end{array}$ \\
\hline 0 & 1 & $118.8 \pm 26.5 a$ & $5.9 \pm 1.3 \mathrm{a}$ & $1020.5 \pm 231.4 \mathrm{a}$ & $51.0 \pm 11.6 \mathrm{a}$ \\
\hline 1 & 1 & $37.2 \pm 21.1 b$ & $1.9 \pm 1.1 \mathrm{~b}$ & $829.4 \pm 99.7 \mathrm{ab}$ & $41.5 \pm 5.0 \mathrm{ab}$ \\
\hline 2 & 1 & $32.3 \pm 10.6 b$ & $1.6 \pm 0.5 b$ & $366.6 \pm 80.0 \mathrm{~b}$ & $18.3 \pm 4.0 \mathrm{~b}$ \\
\hline 1 & 0 & $17.7 \pm 7.4 \mathrm{~b}$ & $0.9 \pm 0.4 b$ & $616.7 \pm 123.7 \mathrm{ab}$ & $30.8 \pm 6.2 \mathrm{ab}$ \\
\hline 1 & 1 & $37.2 \pm 21.1 b$ & $1.9 \pm 1.1 b$ & $829.4 \pm 99.7 \mathrm{ab}$ & $41.5 \pm 5.0 \mathrm{ab}$ \\
\hline 1 & 2 & $22.3 \pm 7.6 b$ & $1.1 \pm 0.4 \mathrm{~b}$ & $758.7 \pm 158.3 \mathrm{ab}$ & $37.9 \pm 7.9 \mathrm{ab}$ \\
\hline
\end{tabular}

Note: Data are mean \pm standard deviation. Different lowercase letters in the same column indicate significant differences $(P=0.05)$ 
Table 5 Influence of plant growth regulators on somatic embryo development of Fraxinus mandshurica

\begin{tabular}{|c|c|c|c|c|c|c|c|c|c|}
\hline \multicolumn{2}{|c|}{$\begin{array}{l}\text { PGR (mg } \\
\left.\mathrm{L}^{-1}\right)\end{array}$} & \multicolumn{2}{|c|}{ Culture for $30 \mathrm{~d}$} & \multicolumn{6}{|c|}{ Culture for $90 \mathrm{~d}$} \\
\hline NAA & $\mathrm{BA}$ & $\begin{array}{l}\text { Globular } \\
\text { embryo (\%) }\end{array}$ & $\begin{array}{l}\text { Heart } \\
\text { shaped embryo (\%) }\end{array}$ & $\begin{array}{l}\text { Torpedo } \\
\text { embryo }(\%)\end{array}$ & $\begin{array}{l}\text { Cotyldon } \\
\text { embryo (\%) }\end{array}$ & $\begin{array}{l}\text { Globular } \\
\text { embryo (\%) }\end{array}$ & $\begin{array}{l}\text { Heart shaped } \\
\text { embryo }(\%)\end{array}$ & $\begin{array}{l}\text { Torpedo } \\
\text { embryo }(\%)\end{array}$ & $\begin{array}{l}\text { Cotyledon } \\
\text { embryo (\%) }\end{array}$ \\
\hline 0 & 1 & $73.2 \pm 3.1$ & $8.4 \pm 1.7 \mathrm{a}$ & $10.4 \pm 2.0$ & $8.0 \pm 2.8 \mathrm{ab}$ & $61.9 \pm 4.2$ & $11.7 \pm 1.6 \mathrm{ab}$ & $12.7 \pm 1.8$ & $13.7 \pm 2.2 \mathrm{a}$ \\
\hline 1 & 1 & $76.4 \pm 6.7$ & $3.9 \pm 1.5 b$ & $15.5 \pm 5.5$ & $4.2 \pm 3.0 \mathrm{ab}$ & $54.6 \pm 7.8$ & $14.5 \pm 2.2 \mathrm{a}$ & $13.6 \pm 3.7$ & $17.2 \pm 3.8 \mathrm{ab}$ \\
\hline 2 & 1 & $65.6 \pm 8.3$ & $2.4 \pm 1.2 b$ & $16.1 \pm 4.5$ & $15.9 \pm 6.6 \mathrm{a}$ & $66.4 \pm 5.6$ & $10.1 \pm 1.9 \mathrm{ab}$ & $14.0 \pm 2.3$ & $9.5 \pm 3.0 \mathrm{a}$ \\
\hline 1 & 0 & $65.4 \pm 10.9$ & $0.2 \pm 0.2 b$ & $26.3 \pm 10.6$ & $8.1 \pm 6.6 \mathrm{ab}$ & $47.3 \pm 4.3$ & $13.6 \pm 1.2 \mathrm{ab}$ & $13.0 \pm 1.0$ & $26.1 \pm 4.9 b$ \\
\hline 1 & 1 & $76.4 \pm 6.7$ & $3.9 \pm 1.5 b$ & $15.5 \pm 5.5$ & $4.2 \pm 3.0 \mathrm{ab}$ & $54.6 \pm 7.8$ & $14.5 \pm 2.2 \mathrm{a}$ & $13.6 \pm 3.7$ & $17.2 \pm 3.8 \mathrm{ab}$ \\
\hline 1 & 2 & $69.7 \pm 8.7$ & $3.6 \pm 1.5 b$ & $25.0 \pm 8.8$ & $1.8 \pm 1.0 \mathrm{~b}$ & $63.1 \pm 9.6$ & $8.9 \pm 1.4 b$ & $12.8 \pm 4.4$ & $15.2 \pm 4.6 \mathrm{ab}$ \\
\hline
\end{tabular}

Note: Data are mean \pm standard deviation. Different lowercase letters in the same column numbers indicate significant differences $(P=0.05)$

is affected by many factors such as plant species, culture conditions, explants age, and the location of explants (Shin et al. 2019). The positive effect of auxin on callus induction may be because the endogenous auxin levels were low in the
F. mandshurica explants. By affecting a variety of auxinrelated enzymes, exogenous auxin can regulate the content of endogenous auxin (Machakova et al. 2008). A study on the Arabidopsis transcriptome showed that the leaf-to-callus

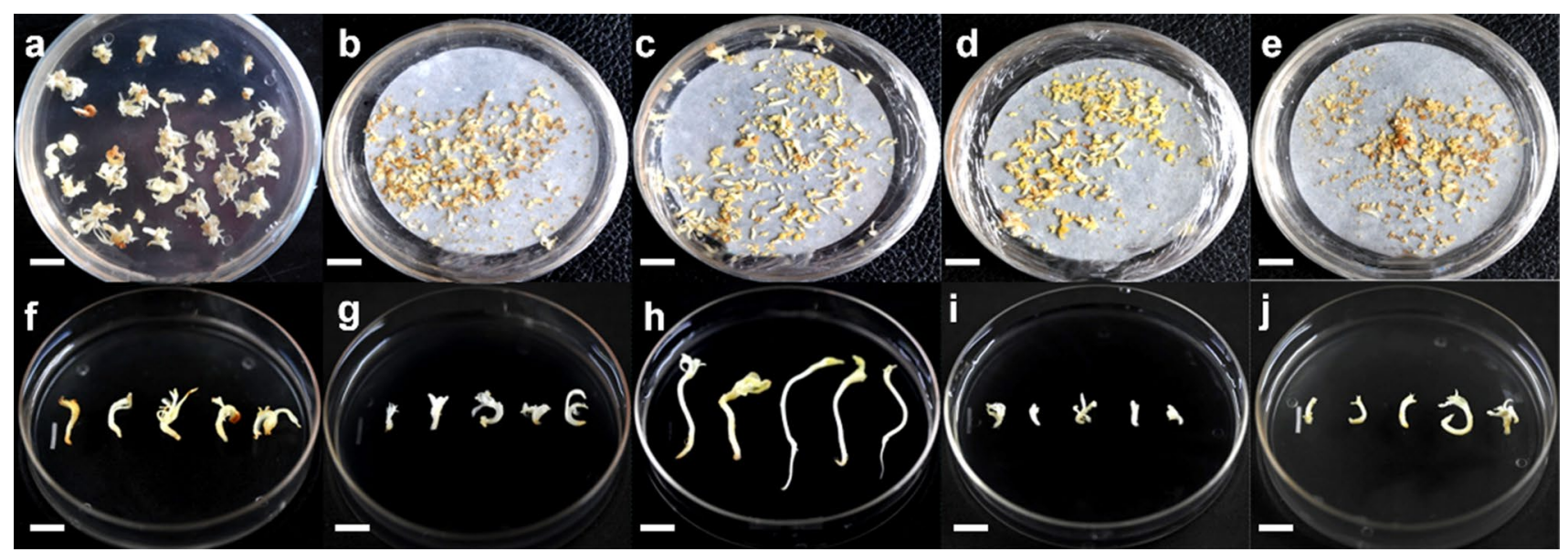

Fig. 3 Somatic embryo maturation process of Fraxinus mandshurica. a: SEs after 30 days of culture on CK; b-e: SEs after 30 days of culture on media containing different concentrations of ABA $(0,1$, 1.5 , and $\left.2.0 \mathrm{mg} \cdot \mathrm{L}^{-1}\right)$; f: Cotyledon-shaped embryos after 30 days of culture on CK and 30 days of culture on basic medium; $\mathbf{g}-\mathbf{j}$ : Cotyledon-shaped embryos after 30 days of culture on media containing different concentrations of $\operatorname{ABA}\left(0,1,1.5\right.$, and $\left.2.0 \mathrm{mg} \cdot \mathrm{L}^{-1}\right)$ and 30 days of culture on basic medium. Scale bars: $1.1 \mathrm{~cm}(\mathbf{a}) ; 1.0 \mathrm{~cm}(\mathbf{b}-\mathbf{j})$

Table 6 Properties of somatic embryos after drying treatment and culture on media containing ABA for 30 days

\begin{tabular}{llllll}
\hline $\begin{array}{l}\text { PGR }\left(\mathrm{mg} \mathrm{L}^{-1}\right) \\
\text { ABA }\end{array}$ & $\begin{array}{l}\text { Cotyledon } \\
\text { Embryos }\left(\mathrm{g}^{-1}\right)\end{array}$ & $\begin{array}{l}\text { Ratio of cotyledon } \\
\text { to embryo length }(\%)\end{array}$ & $\begin{array}{l}\text { Average } \\
\text { length }(\mathrm{mm})\end{array}$ & $\begin{array}{l}\text { Malformed } \\
\text { embryo } \\
\text { percentage } \\
(\%)\end{array}$ & $\begin{array}{l}\text { Developmental morphology } \\
0\end{array}$ \\
\hline 0 & $248.2 \pm 16.0 \mathrm{bc}$ & $32.2 \pm 1.5 \mathrm{a}$ & $3.7 \pm 0.2 \mathrm{a}$ & 70.0 & Translucent; unstretched; different sizes \\
1.0 & $397.0 \pm 27.7 \mathrm{a}$ & $51.0 \pm 1.8 \mathrm{~b}$ & $4.7 \pm 0.2 \mathrm{~b}$ & 20.0 & Milky white; cotyledons stretch out; same size \\
1.5 & $225.7 \pm 16.3 \mathrm{bc}$ & $35.0 \pm 2.2 \mathrm{a}$ & $3.4 \pm 0.2 \mathrm{a}$ & 60.0 & Translucent; unstretched; \\
2.0 & $189.6 \pm 32.7 \mathrm{~b}$ & $46.3 \pm 2.6 \mathrm{~b}$ & $3.3 \pm 0.2 \mathrm{a}$ & 80.0 & Translucent; unstretched; \\
CK & $320.7 \pm 72.1 \mathrm{ac}$ & $52.0 \pm 7.4 \mathrm{~b}$ & $3.2 \pm 0.3 \mathrm{a}$ & 80.0 & Translucent; curly; individual Browning
\end{tabular}

Note: CK, materials cultured on ABA-free medium without drying. Malformed embryos are multi-cotyledonary embryos and incompletely differentiated SEs. Data are mean \pm standard deviation. Different lowercase letters in the same column indicate significant differences $(P=0.05)$ 
process involved the stage of auxin response gene upregulation (He et al. 2012). Wójcikowska et al. (2013) found that an auxin treatment promoted somatic embryogenesis by activating transcription factors, including LEAFY COTYLEDON2 (LEC2), which controls IAA synthesis in explants. In that study, an auxin treatment led increased LEC2 activity, and subsequently activates the YUCCA (YUC) genes, increasing the content of endogenous auxin Perez-Perez et al. (2019). found that the induction of auxin synthesis genes and the accumulation of auxin in cells are related to the requirements of auxin in the initiation and development of somatic embryogenesis.

\section{Proliferation and browning of embryogenic callus}

In the process of callus proliferation, we often choose some plant growth regulators, such as the auxin 2,4-D can not only induce direct somatic embryogenesis, but also is necessary for the process of callus proliferation in indirect somatic embryogenesis (Pasternak et al. 2002). In addition to stimulating auxin responses, 2,4-D can also increase the endogenous IAA level (Li et al. 2011). However, 2,4-D should not be used during the subsequent development and maturation of SEs (Zavattieri et al. 2010). The removal of exogenous 2,4-D was found to trigger IAA polar transport and the formation of an auxin gradient in embryonic callus ( $\mathrm{Su}$ et al. 2009). In the present study, we found that serious callus browning occurred on medium containing 2,4-D, and this became more serious with longer times between subculturing. The degree of browning could be reduced by shortening the subculture period, or by adding anti-browning agents such as ascorbic acid, citric acid, and polyvinylpyrrolidone (data not shown). In olive (Olea europaea) callus, as the length of time between subculture extended, the embryo quality decreased (Bradaï et al. 2016). Similarly, the callus quality began to decrease after 9-year subculture, but some cell lines remained embryogenic after 20 years of subculture in oil palm (Elaeis guineensis Jacq.) (Konan et al. 2010). In that case, the excessive nitrogen demand for polyamine synthesis was one of the most likely causes of the decline in callus quality with extended culture time (Konan et al. 2010). Culture conditions and genotypes are two important factors that affect the embryogenic maintenance of callus (Bradaii et al. 2016). In this study, the embryogenic ability of $F$. mandshurica embryogenic callus did not change significantly after 2-year subculturing. However, further research

Table 7 Properties of embryos after drying treatment, culture on ABA-containing medium, and then culture on PGR-free medium for 30 days

\begin{tabular}{|c|c|c|c|c|c|c|}
\hline $\begin{array}{l}\mathrm{ABA} \\
\left(\mathrm{mg} \cdot \mathrm{L}^{-1}\right)\end{array}$ & $\begin{array}{l}\text { Cotyledon embryo } \\
\text { number }\left(\mathrm{g}^{-1}\right)\end{array}$ & $\begin{array}{l}\text { Ratio of cotyledon } \\
\text { to embryo length }(\%)\end{array}$ & $\begin{array}{l}\text { Average } \\
\text { length }(\mathrm{mm})\end{array}$ & $\begin{array}{l}\text { Browning } \\
\text { percentage }(\%)\end{array}$ & $\begin{array}{l}\text { Rooting } \\
\text { percentage (\%) }\end{array}$ & $\begin{array}{l}\text { Mal- } \\
\text { formed } \\
\text { embryo } \\
\text { percent- } \\
\text { age }(\%)\end{array}$ \\
\hline 0 & $558.0 \pm 78.0 \mathrm{a}$ & $46.0 \pm 2.5 \mathrm{ab}$ & $6.0 \pm 0.3 b c$ & $3.0 \pm 0.9 \mathrm{a}$ & $18.5 \pm 3.8 \mathrm{a}$ & 30 \\
\hline 1.0 & $624.0 \pm 113.8 \mathrm{a}$ & $40.0 \pm 4.5 \mathrm{a}$ & $9.6 \pm 0.8 \mathrm{a}$ & $0.2 \pm 0.2 \mathrm{a}$ & $38.0 \pm 5.1 \mathrm{~b}$ & 10 \\
\hline 1.5 & $269.3 \pm 31.5 b$ & $52.0 \pm 3.7 \mathrm{~b}$ & $5.6 \pm 0.4 b$ & $0.9 \pm 0.5 \mathrm{a}$ & $16.6 \pm 5.3 \mathrm{a}$ & 60 \\
\hline 2.0 & $176.7 \pm 8.5 b$ & $74.0 \pm 2.5 \mathrm{c}$ & $7.2 \pm 0.9 b c$ & $3.1 \pm 0.9 \mathrm{a}$ & $8.2 \pm 2.8 \mathrm{a}$ & 85 \\
\hline CK & $961.7 \pm 123.7 \mathrm{c}$ & $66.7 \pm 4.2 \mathrm{c}$ & $7.8 \pm 0.8 \mathrm{ac}$ & $24.9 \pm 3.8 \mathrm{~b}$ & $12.8 \pm 4.8 \mathrm{a}$ & 30 \\
\hline
\end{tabular}

Note: CK, material was cultured on ABA-free medium without drying. Malformed embryos are multi-cotyledonary embryos. Data are mean \pm standard deviation. Different lowercase letters in the same column numbers indicate significant differences $(P=0.05)$

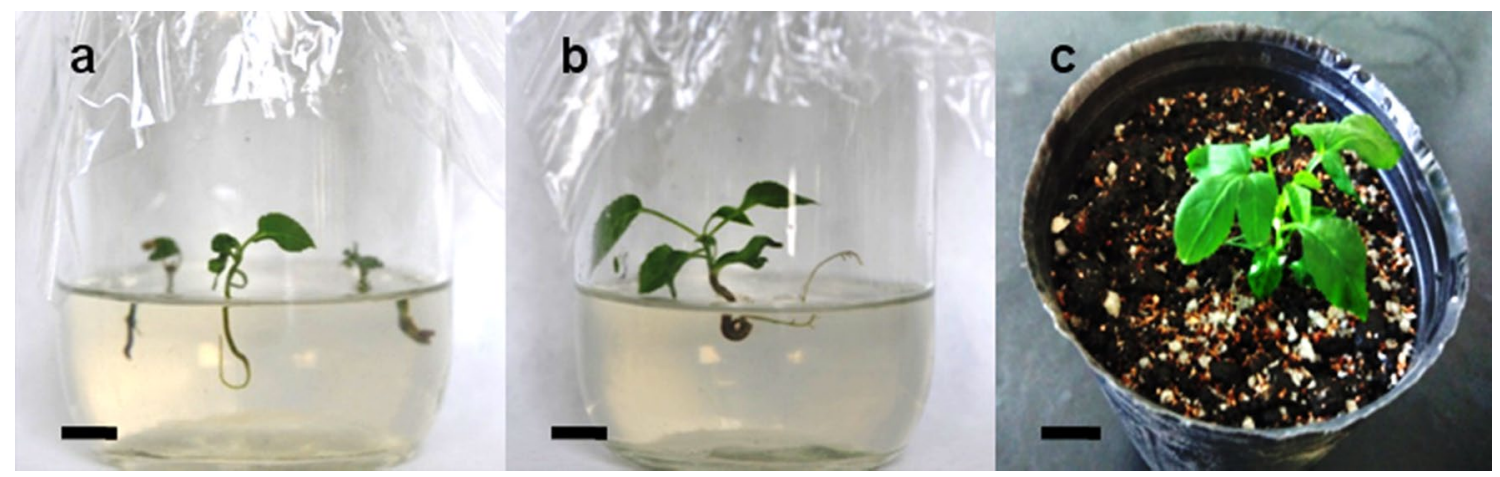

Fig. 4 Germination, acclimatization, and transplanting of Fraxinus mandshurica emblings. a. Plantlet after rooting for 30 days; b. SEs acclimated before transplanting; c. SE seedlings after 60-day transplantation. Scale bars: $1 \mathrm{~cm}(\mathbf{a}, \mathbf{b}) ; 5 \mathrm{~cm} \mathrm{(c)}$ 
Table 8 Germination and rooting of somatic embryos of Fraxinus mandshurica

\begin{tabular}{llc}
\hline Culture medium & Rooting percentage (\%) & $\begin{array}{l}\text { Germination } \\
\text { percentage }(\%)\end{array}$ \\
\hline GM I: $1 / 3 \mathrm{MS}+0.01 \mathrm{mg} \cdot \mathrm{L}^{-1} \mathrm{NAA}$ & $37.5 \pm 7.2 \mathrm{a}$ & $26.4 \pm 6.1 \mathrm{a}$ \\
GM II: $1 / 3 \mathrm{MS}+0.01 \mathrm{mg} \cdot \mathrm{L}^{-1} \mathrm{NAA}+2 \mathrm{~g} \cdot \mathrm{L}^{-1}$ activated carbon & $25.0 \pm 4.8 \mathrm{a}$ & $13.9 \pm 7.4 \mathrm{ab}$ \\
GM III: $1 / 3 \mathrm{MS}+1.0 \mathrm{mg} \cdot \mathrm{L}^{-1} \mathrm{IBA}+1.0 \mathrm{mg} \cdot \mathrm{L}^{-1} \mathrm{IAA}$ & $0 \mathrm{~b}$ & $5.6 \pm 5.6 \mathrm{~b}$ \\
GM IV: $1 / 3 \mathrm{MS}+0.5 \mathrm{mg} \cdot \mathrm{L}^{-1} \mathrm{IBA}+0.5 \mathrm{mg} \cdot \mathrm{L}^{-1} \mathrm{IAA}$ & $27.8 \pm 11.1 \mathrm{a}$ & $16.7 \pm 0 \mathrm{ab}$ \\
\hline
\end{tabular}

is required to determine whether the embryogenic ability of F. mandshurica embryogenic callus changes during longterm preservation, and the key factors affecting any changes.

\section{Differentiation of embryogenic callus}

In plant cell division and differentiation, auxin and cytokinin are key regulators, and the balance between them plays an important role in SE development (Binte and Wagiran 2018; Ming et al. 2019). Although the existence of 2,4-D induced the embryogenic potential of callus, cytokinin was required for the development of SEs during subculturing (Wang et al. 2014). Our results showed that, at the early stage of callus differentiation, $F$. mandshurica callus differentiation was promoted by BA but inhibited by NAA. In the growth and development of Arabidopsis, the polar transport of endogenous auxin is the key factor (Liu et al. 2017). The gradient of endogenous auxin and polar auxin transport influenced by PINFORMED1(PIN1) were identified as the key factors for WUSCHEL (WUS)-induced somatic embryogenesis (Fehér 2019). In Arabidopsis, a short-term low concentration of cytokinin can promote somatic embryogenesis, but if the concentration of cytokinin is too high, it can inhibit polar auxin transport, thus inhibiting somatic embryogenesis (Bernula et al. 2020). Similarly, in our study, when the concentration of BA in the medium was increased, callus differentiation of $F$. mandshurica was inhibited. Cytokinin inhibits the expression of LEC2 and FUSCA 3 (FUS3), the key transcription factors in somatic embryogenesis (Horstman et al. 2017; Bernula et al. 2020).

\section{Maturation of somatic embryo}

SE maturation is the key step of plant transformation during somatic embryogenesis. In the process of SE maturation, the ecology and morphology have changed. With the production and accumulation of storage materials, SE changes from transparent to milky white (The standard of different species maturity; Márquez-Martín et al. 2011). In banana (Musa spp.), drying at $25 \pm 1{ }^{\circ} \mathrm{C}$ for $2 \mathrm{~h}$ was shown to significantly improve the SE induction rate and maturation rate (Natarajan et al. 2020). Similarly, a partial drying treatment was shown to significantly improve the regeneration ability of a Malaysian rice cultivar (Oryza sativa; Ming et al. 2019). In our study, the immature embryos placed onto MS $1 / 2$ medium supplemented with $1 \mathrm{mg} \mathrm{L}^{-1} \mathrm{ABA}$ after drying showed the best maturation rate, and the cotyledons were elongated and milky white. In the future, the differentiation of embryogenic callus may be further improved by optimizing the period of culture on ABA-containing medium, as well as the osmotic pressure of the medium and the photoperiod.

\section{Somatic embryo rooting and plant regeneration}

The formation of roots from embryos is an important step in a somatic embryogenesis system, as it determines whether the production of SE seedlings can be industrialized and commercialized. In general, reduced-strength WPM or MS media ( $1 / 2$ or $1 / 3$ strength) can increase the rooting capacity of most plants (Du and Pijut 2008). Plant growth regulators affect the germination of SEs. For example, the regeneration of plants of a Malaysian rice cultivar were weak without NAA (Binte and Wagiran 2018). The type of sugar and the concentration of auxin were found to significantly affect the number of roots formed from SEs of date palm (Phoenix dactylifera; Ibrahim et al. 2009). In this study, the highest SE germination rate and rooting percentage $(26.4 \%$ and $37.5 \%$, respectively) were on medium containing $0.01 \mathrm{mg} \cdot \mathrm{L}^{-1}$ NAA. Most SE seedlings grew normally, and the rooting rate achieved in this study was higher than that achieved previously (Yang et al. 2013, rooting percentage 27.1\%). Further research is needed to improve the quality of SEs, the rate of SE formation, and the quality of SE seedlings.

\section{Conclusion}

Immature cotyledons of $F$. mandshurica were used as explants to establish an indirect somatic embryogenesis system through callus. The callus proliferated and differentiated into SEs. Compared with previous methods, the methods used in our study resulted in increased yield of SEs and better synchronization of SE development. Using these methods, complete regenerated plants were obtained. These results lay the foundation for the preservation of germplasm resources, and for the molecular and large-scale breeding of F. mandshurica. 
Open Access This article is licensed under a Creative Commons Attribution 4.0 International License, which permits use, sharing, adaptation, distribution and reproduction in any medium or format, as long as you give appropriate credit to the original author(s) and the source, provide a link to the Creative Commons licence, and indicate if changes were made. The images or other third party material in this article are included in the article's Creative Commons licence, unless indicated otherwise in a credit line to the material. If material is not included in the article's Creative Commons licence and your intended use is not permitted by statutory regulation or exceeds the permitted use, you will need to obtain permission directly from the copyright holder. To view a copy of this licence, visit http://creativecommons.org/licenses/by/4.0/.

\section{References}

Bernula D, Benkő P, Kaszler N, Domonkos I, Valkai I, Szőllősi R, Ferenc G, Ayaydin F, Fehér A, Gémes K (2020) Timely removal of exogenous cytokinin and the prevention of auxin transport from the shoot to the root affect the regeneration potential of Arabidopsis roots. Plant Cell Tiss Org 140(2):327-339

Binte Mostafiz S, Wagiran A (2018) Efficient callus induction and regeneration in selected indica rice. Agron J 8(5):77

Bradaï F, Pliego-Alfaro F, Sánchez-Romero C (2016) Long-term somatic embryogenesis in olive (Olea europaea L.): influence on regeneration capability and quality of regenerated plants. Sci Horitic 199:23-31

Chen J, Zhang Y, Li T, Wang P, Wang G, Shi J (2012) Study on origin and development of somatic embryos of Liriodendron hybrids. J Nanjing For Univ (Nat Sci Edition) 36(1):16-20 (in Chinese)

Chen TT, Wang PK, Zhang JJ, Shi JS, Cheng TL, Chen JH (2019) Effects of combined ABA and ZT treatment on somatic embryogenesis and development of liriodendron sino-americanum. Sci SilvaeSinicae 55(3):64-71 (in Chinese)

Cong JM, Shen HL, Li YH, Zhang P, Yang L, Huang J (2012) Physiological and biochemical status of different-types of explants in somatic embryogenesis of Fraxinus mandshurica. J South China Agri Univ 33(1):48-52 (in Chinese)

Corredoira E, Ballester A, Ibarra M, Vieitez AM (2015) Induction of somatic embryogenesis in explants of shoot cultures established from adult Eucalyptus globulus and E. saligna $\times$ E. maideniitrees. Tree physiol 35(6):678-690

Corredoira E, Valladares S, Martínez MT, Vieitez AM, San José MC (2013) Somatic embryogenesis in Alnus glutinosa (L.) Gaertn. Trees 27(6):1597-1608

Du N, Pijut PM (2008) Regeneration of plants from Fraxinus pennsylvanica hypocotyls and cotyledons. Sci Horitic 118(1):74-79

Fehér A (2019) Callus, dedifferentiation, totipotency, somatic embryogenesis: what these terms mean in the era of molecular plant biology? Front plant sci 10:536

Guan Y, Li SG, Fan XF, Su ZH (2016) Application of somatic embryogenesis in woody plants. Front plant sci 7:938

He CS, Chen XF, Huang H, Xu L (2012) Reprogramming of $\mathrm{H} 3 \mathrm{~K} 27 \mathrm{me} 3$ is critical for acquisition of pluripotency from cultured Arabidopsis tissues. PLoS Geneti 8(8):e1002911

Horstman A, Bemer M, Boutilier K (2017) A transcriptional view on somatic embryogenesis. Regeneration 4:201-216

Ibrahim K, Alromaihi KB, Elmeer KMS (2009) The combined role of sucrose with IBA and NAA in rooting of date palm somatic embryos cv. Khanaizi Plant Tiss Cult Biotech 19(2):127-132

Jiang RC, Peng FR, Tan PP (2014) Somatic embryogenesis and the physiological and biochemical characteristics in Catalpa fargesii Bur. f. duclouxii (Dode) Gilmour. China Forestry Science and Technology 1:7 (in Chinese)
Khan T, Reddy VS, Leelavathi S (2010) High-frequency regeneration via somatic embryogenesis of an elite recalcitrant cotton genotype (Gossypium hirsutum L.) and efficient Agrobacterium-mediated transformation. Plant Cell Tiss Org 101(3):323-330

Konan KE, Durand-Gasselin T, Kouadio YJ, Flori A, Rival A, Duval Y, Pannetier C (2010) In vitro conservation of oil palm somatic embryos for 20 years on a hormone-free culture medium: characteristics of the embryogenic cultures, derived plantlets and adult palms. Plant cell rep 29(1):1-13

Lelu-Walter MA, Gautier F, Eliášová K, Sanchez L, Teyssier C, Lomenech AM, Metté CL, Hargreaves C, Trontin JF, Reeves C (2018) High gellan gum concentration and secondary somatic embryogenesis: two key factors to improve somatic embryo development in Pseudotsuga menziesii [Mirb.]. Plant Cell Tiss Org 132(1):137-155

Lelu-Walter MA, Thompson D, Harvengt L, Sanchez L, Toribio M, Pâques LE (2013) Somatic embryogenesis in forestry with a focus on Europe: state-of-the-art, benefits, challenges and future direction. Tree Genet Genomes 9(4):883-899

Li M, Wang S, Feng D (2011) The advance of plant somatic embryogenesis and development. Chin Agric Sci Bull 27(03):237-241 (in Chinese)

Liu CP, Yang L, Shen HL (2015) Proteomic analysis of immature Fraxinus mandshurica cotyledon tissues during somatic embryogenesis: effects of explant browning on somatic embryogenesis. $j$ mol sci 16(6):13692-13713

Liu Y, Dong Q, Kita D, Huang JB, Liu G, Wu X, Zhu X, Cheung AY, Wu HM, Tao LZ (2017) RopGEF1 plays a critical role in polarauxin transport in early development. Plant Phys 175(1):157-171

Lu D, Wei W, Zhou W, McGuigan LD, Ji FY, Li X, Xing Y, Zhang Q, Fang KF, Cao QQ, Qin L (2017) Establishment of a somatic embryo regeneration system and expression analysis of somatic embryogenesis-related genes in Chinese chestnut (Castaneamollissima Blume). Plant Cell Tiss Org 130(3):601-616

Machakova I, Zazimalova E, George EF (2008) Plant growth regulators I introductions auxins their analogous and inhibitors. In: George EF, Hall MA, De Klerk GJ (eds) Plant propagation by tissue culture, 3rd edn. vol 1. Springer, Dordrecht, pp 175-204

Márquez-Martín B, Sesmero R, Quesada MA, Pliego-Alfaro F, Sánchez-Romero C (2011) Water relations in culture media influence maturation of avocado somatic embryos. J plant phys 168(17):2028-2034

Ming NG, BinteMostafiz S, Johon NS, Zulkifli A, Saliha N, Wagiran A (2019) Combination of plant growth regulators, maltose, and partial desiccation treatment enhance somatic embryogenesis in selected malaysian rice cultivar. Plants 8(6):144

Natarajan N, Sundararajan S, Ramalingam S, Chellakan PS (2020) Efficient and rapid in-vitro plantlet regeneration via somatic embryogenesis in ornamental bananas (Musa spp.). Biologia 75(2):317-326

Orłowska A, Kępczyńska E (2020) Oxidative status in Medicago truncatula Gaertn. non-embryogenic and embryogenic tissues with particular reference to somatic embryogenesis. Plant Cell Tiss Org 140(1):35-48

Ozudogru EA, Capuana M, Kaya E, Panis B, Lambardi M (2010) Cryopreservation of Fraxinus excelsior L. embryogenic callus by onestep freezing and slow cooling techniques. Cryo Lett 31(1):63-75

Park YS (2014) Conifer somatic embryogenesis and multi-varietal forestry. In: Fenning T (ed) Challenges and Opportunities for the World's Forests in the twenty-first Century. Springer, Dordrecht, pp 425-439

Pasternak TP, Prinsen E, Ayaydin F, Miskolczi P, Potters G, Asard H, Onckelen HAV, Dudits D, Fehér A (2002) The role of auxin, pH, and stress in the activation of embryogenic cell division in leaf protoplast-derived cells of alfalfa. Plant Physiol 129(4):1807-1819 
Perez-Perez Y, El-Tantawy AA, Solis MT, Risueno MC, Testillano PS (2019) Stress-induced microspore embryogenesis requires endogenous auxin synthesis and polar transport in barley. Front plant sci 10:1200

Shin U, Chandra R, Kang H (2019) In vitro and ex vitro propagations of astilboidestabularis (Hemsl.) Engl. as a rare and endangered species. J Hort 6(260):2376-354

Solórzano-Cascante P, Sánchez-ChiangJiménez NVM (2018) Explant type, culture system, 6-benzyladenine, meta-topolin and encapsulation affect indirect somatic embryogenesis and regeneration in Carica papaya L. Front plant sci 9:1769

Su YH, Zhao XY, Liu YB, Zhang CL, O’Neill SD, Zhang XS (2009) Auxin-induced WUS expression is essential for embryonic stem cell renewal during somatic embryogenesis in Arabidopsis. Plant J 59(3):448-460

Sun GJ, Kong DM, Zhang LJ, Shen HL (2010) Effect of collection time and source tree of zygotic embryo explants on somatic embryogenesis of Fraxinus mandshurica. J Northeast For Univ 38(1):28-30 (in Chinese)

Us-Camas R, Rivera-Solís G, Duarte-Aké F, De-la-Pena C (2014) In vitro culture: an epigenetic challenge for plants. Plant Cell Tiss Org 118(2):187-201

Wang YY, Chen FJ, Wang YB, Li XL, Liang HW (2014) Efficient somatic embryogenesis and plant regeneration from immature embryos of TapisciasinensisOliv., an endemic and endangered species in China. Hort Sci 49(12):1558-1562
Wójcikowska B, Jaskóła K, Gąsiorek P, Meus M, Nowak K, Gaj MD (2013) LEAFY COTYLEDON2 (LEC2) promotes embryogenic induction in somatic tissues of Arabidopsis, via YUCCA-mediated auxin biosynthesis. Planta 238(3):425-440

Yang L, Bian L, Shen HL, Li YH (2013) Somatic embryogenesis and plantlet regeneration from mature zygotic embryos of Manchurian ash (Fraxinus mandshuricaRupr.). Plant Cell Tiss Org 115(2):115-125

Yang L, Liu HN, Zhang DY, Wei C, Shen HL (2017) Effect of plant growth regulators and osmoticums on somatic embryogenesis of Fraxinus mandshuricarupr. Bull Botan Res 37(5):682-689 (in Chinese)

Zavattieri MA, Frederico AM, Lima M, Sabino R, Arnholdt-Schmitt B (2010) Induction of somatic embryogenesis as an example of stress-related plant reactions. Electro J Biotech 13(1):12-13

Zhang LJ, Zhao LM, Lu XJ, Shen HL (2015) Callus Induction and Somatic Embryogenesis from Zygotic Cotyledons and Hypocotyls of Fraxinus mandshurica Rupr. Mol Plant Breed 13(7):1645-1652

Zhang Y, Shen HL (2007) Control of synchronization for Plant somatic embryogenesis. Plant Phys Commun 43(3):583-587 (in Chinese)

Publisher's Note Springer Nature remains neutral with regard to jurisdictional claims in published maps and institutional affiliations. 